\title{
Apologia i kreacja. O przyjaźni Tadeusza Nalepińskiego z Tadeuszem Micińskim
}

Mariola Małecka 


\section{Mariola Małecka}

\section{Apologia i kreacja. O przyjaźni Tadeusza Nalepińskiego z Tadeuszem Micińskim}

\footnotetext{
Ś ród autorów najmbodszych słyszymy bardzo wiele ech, ale mało głosów" — pisze Jan 9 $S$ Lorentowicz w 1911 roku w artykule o Tadeuszu Nalepińskim'. W tuzinach ozdobnie drukowanych zbiorków trudno odnaleźć świeżość talentów:
}

Drobniutka zaledwie garstka wierzy, że ma naprawdę coś do powiedzenia, że przychodzi z nowym zarysem świata uczuć i myśli...

Do tej garstki Lorentowicz zalicza Tadeusza Nalepińskiego, który jest dla niego jedną z najciekawszych indywidualności w tym pokoleniu, i którego głos - choć jeszcze nie osiągnąl dojrzałego, pełnego wyrazu — przybiera „niepospolite formy ksztaltowania się wybitnego talentu".

W kilka miesięcy po szkicu Lorentowicza, w ,Prawdzie” ukazuje się artykuł Eustachego Czekalskiego Pan Nalepinski jako herold idei Miciniskicgoº odmawiający Nalepińskiemu samodzielności myślenia i uznający, że twórca ten „w stosunkı do Micińskiego zajmuje zawsze stanowisko apologety".

Sąd ten utrzymywat się powszechnie przez wiele lat, umacniany przez kolejnych badaczy i komentatorów literatury. Na zależność od Tadeusza Micińskiego wskaże w swej pracy o neoromantyzmie Julian Krzyżanowski ', zaliczając go do grona epigonów, którzy z miennym

' J. Lorentowicz, Tadensz Nalepinski, „Literatura i Sztuka” (dod. do .. Nowej Gazety") 1911 mr 11. s.1.

2E. Czckalski. Pan Nalcpinski jako herold idei Micinskicko, .Prawda" 1911 ur 50-51.

3. Krzyżanowski. Neoromantyz-m polski 1890-1918. Wrocław 1980, s. 50. Na wplyw Tadeusza Micińskiego na Tadeusza Nalepinskiego zwrócili równicż uwagę miçdzy innymi: W. Feldman, ITspótczessma literatura polska 1864-1918. t. 2, Kraków 1985, s. 195: E. Kozikowski, Tádeus: Nalepiniski, .Osnowa” 1969, zima: T. Hiż, Przed 20 laty odeszli du'aj pecti. .,Gazeta Polska” 1938 n1r 315. s. 3. 
skutkiem usilowali kroczyć szlakiem autora Nictoty. Zaś Jacek Kolbuszewski w artykule Tatry, mitośc i śmieró pisze:

Może tylko jako ów „herold idei Micińskiego” i głosiciel jego wielkości, którą na różne sposoby usiłował mnożyć, zasługiwałby Nalepiński na większe zainteresowanic $(\ldots)^{+}$.

Nieliczni, jak piszący o Nalepińskim przed II wojną światową Stanisław Pazurkiewicz, zwracając uwagę na pokrewierístwo jego twórczości z twórczością Micińskiego, dostrzegali jej indywidualizm:

Wyobraźnia Nalepińskiego niczym nie skrępowana, ale nie ekscentryczna, przyzwyczajona do wysokich, niebosiężnych lotów, przypomina czasem fantazję Micińskiego, bujającą np. w lirykach W mroku gurazd w regionach kosmosu lub tworząca przedziwne, gorączkowe wizje, oszałamiające swym niesamowitym przepychem, np. w Bazylissie Te famm. Dlatego zapewne Nalepiński poznal się najlepicj na utworach Micińskiego i stal się najgłębszym ich komentatorem. Zachodzi jednak między obu postaciami wyraźna różnica — pomino że obydwaj są o śmiałym polocie ducha twórcami nawiązującymi do mistyki z epoki romantyzmu, jednak każdy z nich potrafił zachować swe indywidualne oblicze ${ }^{5}$.

Różnice te jednak nie stały się przedniotem zainteresowania i Nalepiński pozostał w badaniach literackich apologeta swego mistrza - Tadeusza Micińskiego. Kim był w istocie na ten temat mówiono niewiele. Był równiez swego mistrza przyjacielem, co nie oznaczalo jednak bezkrytycznego naśladownic twa, kompensującego brak talentu i zdolności kreacji.

Przyjaźń ze starszym o dwanaście lat Tadeuszem Micińskim nawiązala się prawdopodobnie jeszcze w czasie studiów filozoficznych na Uniwersytecie Jagiellońskim w latach 1902-1905 $5^{-6}$. Szkoda, że nie udało się dotychczas odnaleźć ich wspólnej korespondencji ${ }^{7}$. Może jednak ważniejsze od dowodów osobistej życzliwości są dowody wzajemnego poparcia

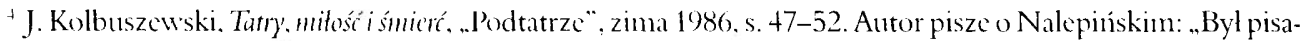
rzem drugorzędnym i jak zawsze wszyscy pisarze niższego lotu w nicodkrywczych i pozbawionych znamior artystycznego indywidualizmu utworach jawi siç on dzisiaj jako banalnie typowy przedstawicicl swojej epoki" P'isząc o jego tatrzaniskich nowclach. styl opowiadania Homo nactus z tomu Kazia ocenia jako ..belkot, pozba. wiony sensu a stanowiący pierwsze popluczyny po Nietocie Micińskicgo, patologicznic powykręcane motyw! wiclkicj literatury mlodopolskicj, świadectwo wypalania siç cpoki”.

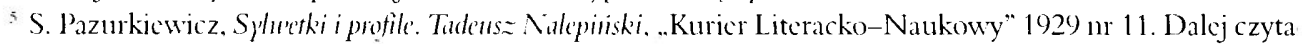
my: „postarany siç to wykazać obszennicj w oddzichnym artykule. Na razic tylko clecemy zaznaczyć, ź i Chrzest (szczególnie rapsod drugi II'Tutrach) Nalcpińskicgo, i Nictota, ksigga tajemma Tatr Micińskicgo, two rzące nowy okres w dzicjach literatury tatrzańskicj, zashugują na glębsze, niz dotąd, zainteresowanie". Od dziclnego artykulu na ten temat Stanishaw Pazurkicwicz jednak nic napisat.

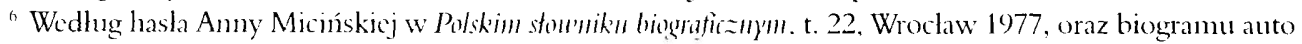

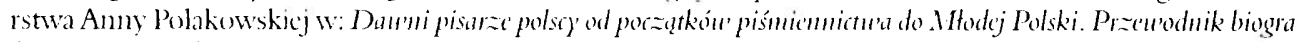

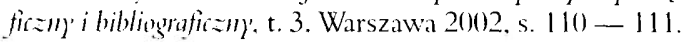

O tym, ze istniala świadczy chociażby list do redaktora warszawskicgo w sprawic Walki o Chnjstusa (rps Bib lioteki Narodowcj w Warszawic, sygn. III 2674: Listy literatów i uczonycl polskich. glównic z XIX wicku .przed paru tygodniani Mic iński w liście do mn ic [podkr. M. M. oświadezyl. ze dotychezas nit 
w twórczych staraniach, pokrewieństwo myśli i poglądów. Może, wyjaśniając również różnice między nimi, uda się wskazać na stopień zależności „ucznia” od „mistrza” i wythumaczyć dzicje recepcji prawie dziś zapomnianego Tadeusza Nalepińskiego.

Spróbujmy odnaleźć miejsca, w których krzyżowały się ich drogi, podczas podróży i w sferze twórczości literackiej.

\section{Spotkania na rozstajach}

Kiedy w roku 1904 Nalepiński debiutuje tomem poezji Gaśnienie, Miciński pisze poemat Niedokonany. Już w Gaśnienin niektórzy dostrzegają patronat idei Micińskiego. Mimo że w tomie tym sporo jest młodopolskiej maniery, lez i tęsknoty bez granic, w istocie można odnaleźć fragmenty godne bohaterów lirycznych poezji Micińskiego, wyrażające samotność, cierpienie, ale i monumentalizm spojrzenia na świat z kosmicznego dystansu.

W lipcu 19()4 roku obaj podpisują się pod listanni z protestem przeciwko nieprzebierającym w środkach atakom na "Chimerę” i koncepcję ,nowej sztuki”, zwalczanej przez Stanislawa Brzozowskiego w imię , ideologii czynu”". W liście do Wladysława Reymonta ${ }^{11}$ Miciński wyjaśnia cel tych listów:

Chcielibyśny dać początek jakiejś uczciwej opinii literackiej i położyć w ten sposób tamę rozwielmożniającemu się coraz bardzicj bandytyzmowi literackiemu.

Ta „wojująca” postawa zawsze będ zie łączyć Micińskiego i Nalepińskiego. W latach 1904-1906 często bywają w Zakopanem, spędzając czas w towarzystwie rodziny Witkiewiczów:

W tym czasie Tadeusz jeszcze przyjaźnil się z Witkacym, w domu Witkiewiczów był zawsze serdecznie witanym gościem. (...) obaj chłopcy byli zafascy-

o jego książce glosu nic zabral...". Spuścizna Tadeusza Micińskicgo, sprowadzona staraniem Andrzcja Struga w 1923 roku i przckazana Arturowi Górskiemu, prawie calkiem ukegla zniszczeniu w 194t roku. Część korespondencji Micińskiego znajduje siç w Bibliotece Narodowej w Warszawic [dalcj: BN]. Zaklad Narodowym imienia Ossolińskich we Wrochawiu, Archiwach Polskicj Akademii Nauk w Warszawie i w Krakowic oraz w Muzcum Literatury w. Warszawic i Muzeum I Listorycznym Miasta Krakowa. Zachowanc listy Nalepińskicgo znajdują siç w tychize archiwach oraz w Bibliotece Micjskicj w Bydgoszczy, w Muzeun Tatrzańskim w Zakopanem i w Archiwam Literatury i Sztuki w Moskwie. Zob. takze: Korcspondenga Tadensaa Micinskiego, opr. T. Wróblewska. .Miesiçcznik Litcracki" 1969 nr 11: K. Koliniska. List' do nickodhan)'ch. Katowice 1983. Oprzyjaźni obu twórców pisała siostra Tadeusza Nalcpiniskiego. I Talina Nalepińska-P'icczarkowska: Tadérsz Nalepinski na tle rodziny',.. Twórczość" 1988 1n 11. s. 76-90. W jej posiadaniu znajdowala siç korespondencja pisarza. którcj los jest dzisiaj nicznany.

${ }^{*}$ Wedlug Amny Micińskicj, op. cit.

"Chodzi o slynną bataliç o .nową sztukę", zapoczątkowaną przez Stanislawa Brzozowskicgo w 1904 roku na

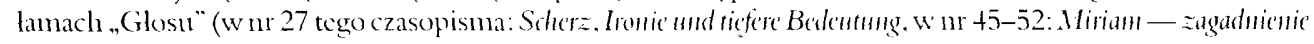
kultur')

19 List z 7 lipca 1904. [w:] Listy różnych osób do różnych z lat 1857-1939. [Rę̧opis]. (Z papicrów Zcnona Przesmyckicgo, BN). List ten podpisany jest przez Jana Lemańskicgo i Tadeusza Micińskiego. 
nowani Tadeuszem Micińskim, chodzili z nim w góry, uważali go za swego Mistrza..."

Kiedy zaś ukazuje się książkowe wydanie pracy doktorskiej Nalepińskiego (obronionej w $19(07$ roku po studiach w Pradze u prof. Tomasza Masaryka), zatytulowanej On idzie! Rzecz o Królu-Duchu Rosji, Miciński w „Literaturze i Sztuce” (dodatku do „Nowej Gazety”) publikuje recenzję ${ }^{12}$ pełną zrozumienia dla zawartej w tej pracy myśli, podziwu dla jej ,języka iskrzącego jak lawa wśród nocy” i jej autora, którego nazywa „młodym wizjonerem”.

W tym czasie Miciński powierzył Nalepińskiemu przekład na rosyjski Bazylissy' Teofanu, zatytułowany później: Wazilissa prickrasnaja (Bazilissa Ticofanu ili "' mrokie zototogo zamka). Tragedija u' 5 diejstu'ijach iz istorii Wizantii Xu'rek'r. Pierieu'ods rukopisi, sou'miestie sautorom, Tadicusza Naliepinskogo ${ }^{13}$. Pisząc do Wilhelma Feldmana z Pragi (8 maja 1907 roku) ${ }^{1+}$, Nalepiński wyznaje:

Thumaczylem Micińskiego Bazy'lissę con annore, ale tyle mi to czasu pochłonęto i pochłania - ze nie obliczywszy się z czasem ani z granicami przyjaźni, spostrzegłem, żem wpadł w ogromne tarapaty pieniężne, nie zapewniwszy sobie na niej żadnych dochodów.

Przez cale życie Micińskiego częste będąjego podróże do Rosji - między innymi do Moskwy i Petersburga. W czerwcu 1906 roku w liście do Feldmana zapowiada swój wyjazd z Warszawy do Petersburga. Nalepiński zatrzymuje się tam na dłużej we wrześniu 1907. Było to więc kolejne miasto, w którym krzyżowały się ich drogi.

Z pewnościąjednak pozostawali w stalym kontakcie. 6 listopada 1907 Nalepiński zawiadamia Feldmana: „Znikł mi z horyzontu Miciński. Koniecznie muszę się z nim porozumieć”. W jakiej sprawie? Odpowiedź znajdziemy może w kolejnym liście, z 27 listopada: „Oto mam w ręku gotowy własny przekład $\left.B a z y^{\prime / i s y}\right)^{\prime}$ Micińskiego..." Niestety, nie został on wydany.

„Niemal nic nie postanowilem w tej sprawie” — pisze Nalepiński. Zobojętniały dla spraw bieżących z powodu przewleklej choroby ojca, nie jest w stanie pracować, a nawet autoryzować przekładu swojej pracy o Królu-Duchu Rosji:

W dzień przyjazdu dowiedziałem się, że książka moja o Rosji przetłumaczona też na rosyjski, thmacz odwiedził mnie prosząc o autoryzację. Przystałem, bo przekład wspaniały, (...) postawilem jednak za warunek znaczne zmiany, wziąłem do siebie rękopis i... Nic nie zrobiłem prawie do dziś. Nie sposób ${ }^{15}$ !

\footnotetext{
"I I. Nalepinska-Picczarkowska, op. cit., s. 83.

12 .Literatura i Sztuki” (dod. do ..Nowej Gazety”). 1908 nr 19. O ówczesnej recepcji tej pracy - zob.: M. We-

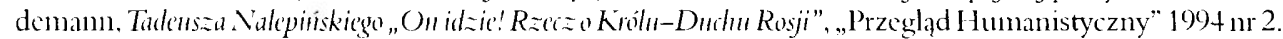

1: Odbitka maszynowa z odręcznymi poprawkami autora i tlumacza (BN IV 7238).

${ }^{4}$ Wszystkie cytowanc listy Tadeusza Nalepiniskiego i Tadeusza Micińskiego do Wilhelma Feldmana pochodza ze zbioróx Ossolincum (II 12282).

15 Stan ten. który opisywał juz we weześnicjszych listach do Feldnnana. wpłynął na jego postawę wobec spraw literackich. W liścic z 26 września 1907 załuje. że Feldman zlożył do druku nie dość dobry artykul o Miciń-
} 
Jedynic pisany nocami dramat Ksiąz' nien'olmy' był w stanie go zająć.

Nie umiem pisać artykułów teraz, przeto chwastem zarasta zagon krytyki literackiej. (...) Jestem w tym dziwnym położeniu, że mam dokąd pisać, mam dużo zaproszeń, a nie mogę. Coś we mule pękło, nie odczuwann rzeczy cudzych. I lirykiem staję się na wskroś.

Zdobywa się na wysilek, by napisać do „Krytyki” i „Tygodnika Ilustrowanego” artykuły o Micińskim i Bazylissie Têfan ${ }^{16}$, wyrażające fascynację twórczością jej autora.

Wobec krańcowo różnego przyjęcia, jakiego doznal ten utwór, Nalepiński broni Micińskiego ze stanowiska ucznia, przekraczającego kolejne kręgi wtajemniczenia dzięki lekturze. Broni zaś argumentami, które zrozumieć może chyba tylko inny wtajemniczony: thumacząc językiem nieprzekładalnym na język racjonalnej narracji, że „skrzydlatym lwem jest Miciński, my zaś sądzimy go jako człowieka”, że „zdobywa on prawo do lucyferyzmu”, zaś Bazylissa to „księga najwyższej tęsknoty, na jaką zdobyl się duch wtajemniczonego w bieg kosmosu”.

Po śmierci ojca w 1908 roku i dluższym pobycie w Petersburgu, związanym z sytuacją rodzinną i współpracą z rosyjskim środowiskiem literackim, w 1910 roku Tadeusz Nalepiński rozpoczyna swą niéustającą podróż po Europie (między innymi do Paryża i Londynu), Bliskim Wschodzie i Stanach Zjednoczonych. Odtąd pisze artykuły i reportaże, w tym dla „Krytyki”, „Bluszczu”, „Sztuki”, „Biesiady Literackiej”, „Sfinksa”, „Świata”, „Tygodnika Ilustrowanego". Regularnie bywa jednak w Petersburgu i Zakopanem ${ }^{17}$; między podróżami zatrzymuje się też w Warszawie, w pensjonacie pani Rodkiewicz przy Chmielnej 29. I nadal zwalcza przejawy niezrozumienia twórczości Micińskiego - mimo że wspiera go raczej piórem niż własną obecnością.

\section{Wilhelm Feldman i walka z ,bazyliszkami”}

Pomostem łączącym obu twórców był miesięcznik „Krytyka” Wilhehma Feldmana, a osoba jego redaktora naczelnego - sprzymierzeńcem ich twórczości. Łączyła ich postawa wobec literatury i kultura dyskusji na jej temat, jaką postulowało to czasopismo, a o którą Miciński i Nalepiński „wojowali” jeszcze za czasów „Chimery” Zenona Przesmyckiego. Ponadto re-

skim, bo chcialby siç wycofać .ze sfery publicystyki tego rodzaju: bardzicj mi bowicm odpowiada krytyka i analiza dzich mistycznych i patologicznych". W liścic z 16 paździcrnika, pisząc o skomplikowanym leczeniu ojca, wyznaje: . Bardzo duzo pomimo to pracuję choć pożtku z tego pewno mało, bo coraz bardzicj wpadam w mistycyzm jakiś intymny. jakby z ksing Krafftebinga |chodzi o Richarda von Krafft-Ebinga, austriackicgo psychiatrę. 1840-19(2)], którcgo nawiasem przestudiowalem na nowo".

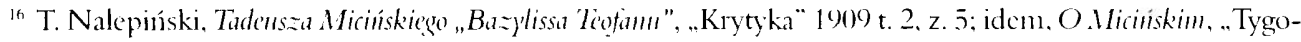
dnik Ilustrowany" 1909 nr 18, s. 357.

${ }^{17}$ Tadeusz Nalepiński „twierdzil, że pracuje mu siç najlepicj w Zakopancm. gdzicś w góralskicj chacie na Olczy czy w Jaszczurówece". (H. Nalepińska-Pieczarkowska, op. cit.. s. 84). W liście z lipca 1911 do przyszlej żony, Cecylii z Trzasków. czytanny: .Trzy dni laziliśmy z Micińskim po górach i dolinach przy cudncj pogodzic. spotykając się i żegnając słoníce i ksiçzyc”. Cyt. za: K. Kolińskia, op. cit. 
daktor „Krytyki” nie ingerowal w nadsyłane teksty i nie naginal ich do własnych poglądów ${ }^{18}$. Najlepiej świadczy o tym życzliwy, choć krytyczny tekst w formie listu do Tadeusza Nalepińskiego, polemizujący z jego artykułem o Nietocie z dwóch wcześnicjszych numerów ${ }^{1 "}$. Podczas pobytu Nalepińskiego w Pradze Feldman przesyłał mu recenzje i artykuły z czasopism polskich. Nalepiński mial też przełożyć na rosyjski jego $W$ spótczesną literaturę polską i podjąć starania o jej wydanie ${ }^{21}$. Staral się też publikować w „Krytyce” najlepsze swe teksty. W liście z 15 września 1907 z Petersburga prosi Feldmana:

Niech mi Pan nie drukuje mizernego artykułu o Micińskim. Dobry on dla „Czasu” i Starzewski zapewne chętnie by go przyjąl do fellietonu ${ }^{21} \ldots$

W zamian obiecuje przestać studium o Judaszu Andrejewa -

...artykuł, którego „Krytyka” nie powinna się wstydzić.

Nalepiński i Miciński wystąpili w obronie swego redaktora, gdy ten stał się obiektem napastliwej kampanii publicystycznej, wywołanej broszurą Jerzego Żuławskiego. Tadeusz Nalepiński odezwał się z Litwy, skąd nadesłal swój podpis pod protestem pisarzy, Tadeusz Miciński - z Warszawy, zamieszczając list otwarty w „Nowej Gazecie”22.

W 1910 roku Nalepiński wydaje w Krakowie Chrest. Fantazje polska, wyraz marzenia o wyzwoleniu narodu polskiego i umiłowania bezwarunkowej wolności człowieka. W tym samym roku pisze wspomniany artykut o Nietocie ${ }^{23}$, który Miciński, mimo zastrzeżeń redakcji, uznaje za niezwykle cenny ${ }^{2+}$. Autor Nietoty jest wdzięczny Feldmanowi za „poważną,

Ix O postawic redaktora naczelnego „Krytyki” Wilhelma Feldmana zob. tcż: A. Jazowski, Poglacdy' Wilhelma Feldmana jako kn'tyka literackicgo. Wroctaw 1970: M. Kitowska-Lysiak. Paralele i kontrasty. Myst o satuce na tamach "Kryt)ki" IIIlledma Feldmana, Lublin 1990.

${ }^{14}$ T. Nalepiński. Tadensza Micinskiego „Nietota”. (Próba u'vktadu), „Krytyka” 1910 z. 4-5; W. F. [W. Feldman], Najutodsi "literaturze polskiej. II. Tadens Nalepinski. .Krytyka” 1910 z. 6. Krytyka artykulu Nalepinískicgo dotyczy kwestii niepodleglości państwowej. Tadeusz Nalepiński uważal, ż za jej cenç „utrzymujemy, przechowujeny w sobic i nic zatracamy aryjskicgo [w sensic: panteistyczncgo, intuicyjnego — przyp. M. M.] patrzenia na świat, na dzicje, na czlowicka i na przyrodę". Wilhclm Feldman wykrył sprzeczność w rozumowaniu Nalepiniskicgo: ., Czy nie zadrżala Panu ręka, gdy pisal Pan to (...) zdanic? Wiem przecie dobrze, wiem, gdzie serce Pańskic. (...) Można gardzić życiem. ale akceptować - pod jakimkolwick bądź warunkien - niewolę? Dojdziemy do filozofii. którcj Pan tak mocno nicnawidzisz, do ultrachrzéścijańskicj zasady, że cierpienia nasze leżą w planic Opatrzności (...)". Zaprotestowat równicż przeciwko nicbezpiecznej wedlug niego propozycji odciçcia Polski od gruntu cywilizacji curopcjskicj. Postulowal wypracowanie kultury polskicj, niczależnej od jednego wzoru kultury: wschodnicgo czy zachodnicgo. Ironizuje: „Ja bowicm, kochany Panic, mogé być Polakiem, "aryjczykiem" chyba nic zostanç".

20 Zob. listy z 8 maja 1907. 15 września 1907.6 listopada 1907.

2. Feldman spehnił życzenic Nalcpińskiego i tekst wycofal; co siçjednak z nim stato - nic wiadomo. Kartoteka zawartości czasopism polskich Adama Bara (w Instytucic Badań Literackich Polskiej Akademii Nauk) nic odnotowuje go.

22 List otwarty T. Micińskiego, „Nowa Gazcta” z 27 maja 19(0); zob. też: U' obronic caci, „Krytyka” 1909 z. 4.

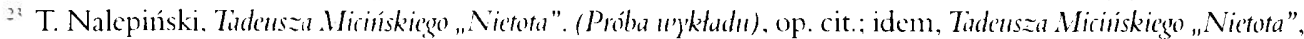
„Literatura i Sztuka” (dod. do ..Nowcj Gazcty”) 1910 n1 24-26.

24 Zob. listy do Feldmama z 24 kwictnia. z maja i czorwca 1910. 
pełną idei krytykę Nalepinískiego". W jednym z listów z Warszawy Miciński panięta także o tym, by zapytać Feldmana:

Czy szanowna Pani Feldmanowa byla łaskawa wysłać p. Dohrn ${ }^{25}$ „Krytykę” $z$ artykulem Nalepiniskiego o Nictocie?

Utwory Nalepińskiego i Micińskiego bezwzględnie skrytykował Andrzej Niemojewski — jako krytyk literacki i religioznawca — na lamach „Myśli Niepodleglej”. Osądził równiez „Krytykę” i Wilhelma Feldmana - „nieuka” i miłośnika odmętów mistyki nowoczesnej. W artykule Dyskusja Galicyjska czytamy:

Mistycyzm nowoczesny jest — o naszych stosunkach mówimy — zawsze tylko objawem nieuctwa. (...) Literatura nasza, która pieni się od uczucia, jest przeraźliwie uboga w idee. (...) Naukowa literatura nie ma zbytu, zaś „krytycy” w rodzaju Feldmanów wprost ośmielają siç szydzić z niej. (...) O wielkich przetomach, dokonywających się w narodzie naszym, taki p. Feldman informuje ogól dopiero wtedy, gdy leciutki oddźwięk tego znajdzie się w jakimś wierszyku Micińskiego. (...) Gdy w górze lwowscy „doktorzy” nieuważnie chodzą i potrącą kamyczek, w dole powstają całe lawinty kothujących się Feldmanów, Nalepińskich i t. $\mathrm{p}^{26}$.

Swiadectwem tamtych dni jest list Nalepińskiego do Feldmana z 4 sierpnia 1910, pisany z Zakopanego, z Olczy - miejsca „dobrowolnego wygnania”:

O sprawach „literackich” wolalbym zapomnieć. Skoro jedıak Miciński i ja zostaliśmy wraz z Panem napadniçci w sposób tak obrzydliwy przez A. Niem. i skoro Pan ma mu odpowiedzieć, pozwolę sobie zwrócić uwagę Pańską na jego metodę krytykowania Nietoty' i Chrzth.

Niemojewski bowiem - krytyk ząajający od innych naukowości w metodzie - według Nalepińskiego popehnia podstawowe błędy interpretacyjne: przytacza cytaty z onyłkami zecerskimi, a słowa postaci przypisuje autorowi poematu, zarzucając 111 megalomanię.

Z powodu odczytu Micińskiego W'spótczesne zagadnienia religijne, wygłoszonego w kwietniu 1911 roku w Warszawie, a potem jego ksiązki Walka o Chry'stusa, Andrzej Niemojewski ponownie dyskutıje z nim zaciekle w „Myśli Niepodległej”, wygloszony referat nazywając publiczną obmowa jego osoby, ukrytą pod płaszczykicm polemiki z jego książą Bóg Je zus ${ }^{27}$. W związku z tym Nalepiński publikuje w „Kurierze Warszawskim” tekst dotyczący Walki

${ }_{25}$ Tadeusz Miciński był spokrewniony z nicmiccką rodziną Dohrnów przez żonç - Mariç Dobrowolską z Baranowskich.

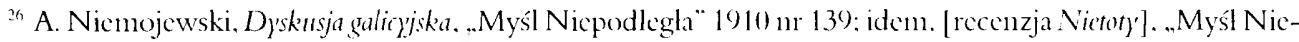
podlegla" 1910 arr 139, 141 s. 1049 .

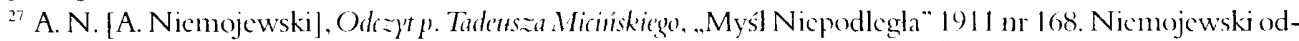

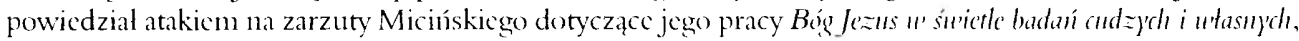
Warszawa 1909. P’iszc tam o Micińskiml. .,Caly ten mozól ponióst wylącznic dlatego, aby wywrzeć zemstę ta- 
o Chrystusa. W liście z 21 listopada 1911 pisze z Londynu do jednego z redaktorów warszawskich:

Załączam przy niniejszym liście artykuł o książce Micińskiego o Chrystusie. Nie zamierzalem o niej pisać, bo zbyt dobrze wiem, jak razi lıdzi nasza przyjaźń, jak latwi są do jątrzenia się na autora Nietoty', o której, jeżeli się nie mylę, dwie osoby prócz mnie zaledwie coś napisaly ${ }^{2 \gamma}(\ldots)$. Przed paru tygodniami Miciński w liście do muie [oświadczyl], że dotychczas nikt o jego książce głosu nie zabrał, że boją się pisać o niej, bo się wydaje „za trudna”. Wspomniał wreszcie, że się widział z Panem i żeście Panowie wyrazili życzenie, bym ja o tym napisał. Przeczytałem więc rzecz raz jeszcze i ślubuję sobie, że powiem nareszcie wszystko, co mam Warszawie z powodı Micińskiego do powiedzenia — napisatem studium, dwurozdziałowy artykul niniejszy. Jest to jedna z najprawdopodobniejszych prac mych, jakie kiedykolwiek napisałem, i może przeceniam jej znaczenie, ale zdaje mi się, że poruszam tam rzeczy w Warszawie konieczne do wyladowania...

W artykule tym powraca do odczytu wygloszonego w Warszawie:

...i tym razem ogół „inteligentny” zainteresowal się najbardziej „pieprzem”, czyli stroną polemiczną. Nie mogły ujść uwagi czytelników, zwłaszcza pism postępowych, systematyczıne od dłuższego czasu napaści na autora Nietoty ze strony Andrzeja Niemojewskiego lub jego giermków (...). Jeżeli (...) postanowitem skreślić kilka słów o nowej książce Micińskiego, to nie po to, aby stać się pośrednikiom pomiędzy nim a jego czytelnikami, lecz po to, aby wskazać tej „zwartej większości”, która się Micińskiego boi, rzecz na której, jak na moście tęczowym nad przepaścią, może się z autorem Nictoty' nareszcie spotkać.

Spotkać się - czyli wyjść naprzeciw, przeciąć drugiemu drogę, nie ominąć go. Wejść w kontakt bezpośredni, szukać miejsc wspólnych, porozumienia.

nią, i jak siç okaże. bezsilną na człowicku. który w krytyce ośniclil siç powiedzieć, iż jego Nietoty' nie zrozumial!". Miciński zarzucal mu miçdzy innyıni nyjaśnianic rcligii za pomocą mitologii astralncj i poddanic Ewangelii kryterium ścislości naukowej jako stadium w ewolucji wicrzeń ludzkich i twór kompilacyjny. Zarzucal mu też traktowanic cwange listów jak ..stetryczalych urzędników w zapadlej prefekturze" (Walka o Chrystısu). Miciński podkreślal sakralıą wartość postawy Chrystusa, choć nie lckceważył historyczncj wiedzy o nim. Według niego jednak głównym kryterium dla religii jest doświadczenie wewnçtrzne, poglçbione przeżycic. Zob. też art. A. Nicmojcwskiego Mit. mist)'ka. mistyfikacja a Miciniski, „Myśl Niepodlegla” 1911 nr 175;

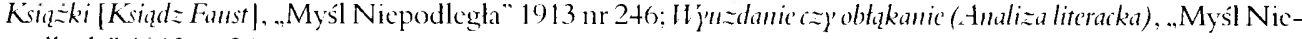
podlegla" 1913 nr $2+8$.

2k O Nictocie pisali równicż: S. Sicroslawski dod. literacki do ..Dzicnnika Poznańskicgo" 1910 nr 36: Savitri

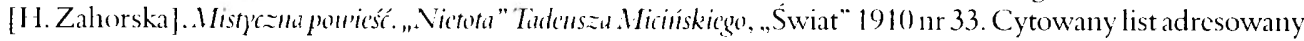
jest prawdopodobnie do redaktora „Kuriera Warszawskiego”, w którym ukazal się artykul Nalepińskiego o Vialice o Chrystusa (1910 nr 339, s. 4-5). W liścic tym czytany: , miakem w pisaniu moc fatalnych trudności do zwalczenia. bo starakem sį̣ ani na chwilę nic zapominać. że piszę dla czytclników "Kúricra»". 
Miciński w liście do Feldmana z 28 sierpnia 1911, pisanym z Drezna, nówi o „otrząśnięciu się z blota warszawskiego":

Trzeba mi będzie wracać. Tatry dały mi moc nerwową, lecz na jak dhugo? Obrzydzeniem przejmują mnie ludzie fałszywi, próżni, złośliwi jak bazyliszki (Nienojewski).

Były w Warszawie osoby, wśród których Miciński i Nalepiniski znaléli jednak oparcie. Miciński pisze przecież do Zenona Przesmyckiego ${ }^{21}$ ze swego mieszkania przy ul. Parkowej 19:

Odebratem Norwida tomy C i E. Zabieram siç do przeczytania z wielką skwapliwością. Czy nie zrobilby mi Pan wielkiej uprzejmości przybywając na g. 6 do mnie w niedzielę? Będzie Dębicki, Lorentowicz, Nalepiński.

Zapleczem walki byl jednak dla obu miesięcznik „Krytyka”. Walki nie tyle nawet z krytykami warszawskimi, co z krytyką racjonalizıjącą, poprzestającą na naukowej analizie pojedynczych części utworu - przeciwną krytyce „rozumiejącej”, podejmującej próbę syntezy utworu, jego calościowego ujęcia, z uwzględnieniem intuicji i subiektywnych, impresyjuych odczuć krytyka. Krytyki podejmującej polemikę, lecz życzliwej, reprezentowanej przez Wilhelma Feldmana ${ }^{3 !}$.

\section{W poszukiwaniu piątej Ewangelii}

Kiedy w latach 1911-1912 w „Sztuce” ukazıje się Xiądz Faust, Nalepiński pisze i przerabia wielokrotnie monodramat liryczny kiaże nicu'olny $y^{31}$. W tym czasie informuje z Zakopanego ${ }^{32}$ :

Nie mam (...) dotąd owego mru „Krytyki” z wierszem Micińskiego, muie zadedykowanym113.

\footnotetext{
${ }^{29}$ Data listu jest nicpewna. Prawdopodobnic jednak zostal on napisany we 1912 roku. Wspomniane tomy pism

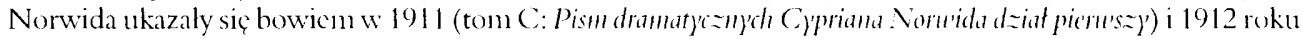

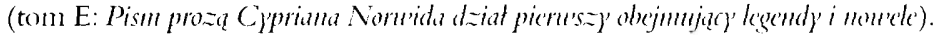

${ }^{30}$ Por. wypowiedź J. Baudouina de Courtenay: ..Pan N [iemojewski Andrzej] zarzuca p. Feldmanowi. zee, różniąc siç ze mną w przckonaniach politycznych, cierpi jednak moje wspólpracowıictwo w" "Krytyce" ( $\mathrm{Nr} 179$. str. 1082). Ja zaś sądzę, że na tym whaśnie polega prawdziwa "wolnonnyślność. Byle tylko szanować siç nawzajem i nie uprawiać szczucia, można w tym sannym czasopiśnic wypowiadać zdania wręcz sobic przeciwne, nic obniżając wcale wartości ctycznej tego czasopisma. Przccież nie jesteśny stadem powtarzającym chóralnie «za panią nnatką pacicrz", alc tylko indywiduani uobywatchnionymi i samodzichnic myślącymi" (O panm - tndrzeju Niemojemskim stow kilka. 1., „Krytyka” 1912 t. 33. s. 43).

${ }^{31}$ W liście do Feldmana. z Londynu z 10 maja 1912 pisze o definitywnymu ukończeniu tego utworu, króry cechuje .,sugestywny liryzm. symbolika. roztrojenic jaźni. Obecny Ksižzę nie ma nic wspólnego z dawnympozostaly tylko te same osoby".

32 List do W. Feldmana z 16 listopada 1912.

${ }^{33}$ T. Miciński. Milości i melandolii śn'iztynia. [Wiersz dedykowany T. Nalepińskiemu]. ..Krytyka“ 1911 z. 5.
} 
Kiedy w 1913 roku Xiądz... ukazuje się drukiem, Nalepiński publikuje w „Tygodniku Ilustrowanym" szkic Pourieść czy Eu'angelia? ${ }^{3+}$. Jego napisanie prawdopodobnie proponował wcześniej Nalepińskiemu Wilhelm Feldman. 7 marca Nalepiński pisal bowiem do Feldmana:

Księdza Fausta znam jedynie z urywków korektowych. (...) Drukowanie opinii o tej książce uważalbym za przyjemność i zaszczyt, gdybym czuł, że potrafię w skupieniu zapanować nad problematem i godnie go oświetlić. Niestety, Warszawa i życie mordownicze w niej, zatrute (...) nasıwa obawy, że nie potrafię nawet znaleźć potrzebnego czasu, wobec licznych zobowiązań, jakie mię tu więżą. D. 28 marca wyjeżdżan do Londynu, na długo. Może tam, przeczytawszy książkę w drodze (dotąd jej nie mam), odetchnąwszy swobodnie, recenzję czy artykul bym napisal. Więc jeśli pilne, to proszę na mnie nie liczyć.

Artykuł ten, napisany w końcu dla „Tygodnika Ilustrowanego”, ujawnia stosunek Nalepińskiego do twórczości mistrza. Ta „na pół powieść, na pól apologia tezy o potrzebie religii dla duszy polskiej współczesnej”, o tym, czym ,duch Polaka mógłby być, czym być powinien, a czym nie jest", zdaniem Nalepińskiego urzeka swym misterium nawet pozytywistów. Broniąc mocy ukrytej w jaźni lud zkiej, mocy Lucyfera przed upadkiem - ukazuje ona wtajemniczonych już w istotę bytu, czlowieka posiadającego moc Doskonałości boskiej:

Miciński z zaparciem się wrodzonego mu pędu do wieszczenia samych tylko cudowności, szarpnąwszy najwewnętrzniejsze pokłady swej własnej mistycznej mitologii, wydarl duclıowi swemu z trzewi dzieło, które oświeca, kształci i dobrą wieść niesie spoleczeństwu. (...) Piekło udręki polskiej pochłonęła w sobie praca nad Księdzem Funstem, ale z piekła tego czytelnik wynosi duszę oczyszczoną, już tęskniącą. (...) Powieść Micińskiego (...) budzi w sercach nie uludy czarowne, lecz świadomość uczuciową, że zginieny, jeśli nas miłość sprawy wspólnej nie pojedna.

Szkic ten stał się powodem listı otwartego od Micińskiego, prawdopodobnie z 21 czerwca. Miciński pisze w nim do swego „ucznia”:

W głębokiej Waszej krytyce, wzruszonej mocą własnego natchnienia, jedno jest wyrażenie, przeciwko któremu muszę zaprotestować. Jest to sam tytu1: Pourieść czy' e'l'angelia?

(...) Piątej ewangelii nie ma, nie będzie i być nie powimno. Wydana pod tym tytułem francuska książka jest wstrętnym nadıżyciem reklamy. I dlatego zestawienia zbyt wysokiego przyjać nie mogę, a po prostu — przez zbyt wielką skalę wymagań lamie ów tytuł wszelką rzeczywistą (jeśli jest) wartość utworu. Jest to bowiem tylko powieść — o przygotowaniu się do Czynu. 
To, że Nalepiński potraktowal Księdza Fansta jako księgę objawienia dla Polaków, wynika nie tylko z jego fascynacji Micińskim. Wiąże się to także z tęsknotą do syntezy polskich kompleksów i nadziei. Będzie do niej dążył w swojej twórczości, a jego szkice krytyczne będą zbieraniem jej elementów, rozproszonych po różnych utworach. W dziełach Tadeusza Micińskiego ją znalazł — stąd ton entuzjastycznie ogłaszanej pewności.

Tadeusz Miciniski uwazal się jednak tylko za twórcę, który nie ma monopolu na prawdę i nie chce budować systemów. Co więcej - cała jego twórczość zdaje się wyrażać tęsknotę za relacyjnym, a nie substancjalnym, kategorialnym traktowaniem czlowieka i jego twórczości, za tworzeniem go w każdej chwili od nowa ${ }^{35}$. Jego siłę dostrzegł w pokorze wobec własnych możliwości i w odwadze ich przekraczania. Nalepiński odczytał przeslanic „mistrza” zbyt dostownie, akcentując glównie narodowe wartości w jego dziele i literalnie odczytując propozycje ich realizacji, na co zwrócił uwage Wilhelm Feldman:

Miciński jest siłą, nie argumentem. A siła ta nie tam spoczywa, gdzie ją zwykle chcą widzieć. (...) Istota jego - stosunek prawdziwie religijny, jedynie religijny, do siebie i do reszty świata ${ }^{36}$.

Dążenie do ideałı, a nie powrót do Ciangesu i mądrości aryjskiej.

W każdym razie podzikich napaściach i pretensjach, które za Xiędza Fansta różne istoty wyjadowily na mnie ${ }^{37}$ — pisze dalej w swym liście otwartym Tadeusz Miciński - Wasze int u i cyjne ujęcie twór czości, jako potrzeby gloszenia tego, co dla artysty jest ewangelia - było też dla moich uczuć spolecznych - dobrą nowiną.

\section{Wyczucie i wiara}

Whaśnie ta intuicyjność w ujmowaniu cudzej twórczości, odnajdywanie w niej tego, co dla piszącego o niejjest najcenniejsze, jest znamienne dla artykułów Tadeusza Nalepińskiego ${ }^{3 x}$.

Od pierwszych tekstów o twórczości Micińskiego w „Tygodniku Ilustrowanym” i „Krytyce" Nalepiński posługuje się językiem, który sam ma cechy poetyckie. Przechwytuje

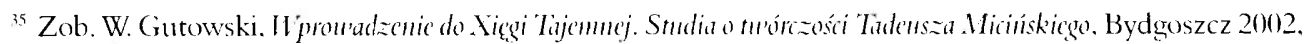
rozdz.: ŹZ'ie nou'e, s. 343.

${ }^{36}$ W. F. [W. Foldman], Najmhodsi "literatmise polskicj, op. cit.

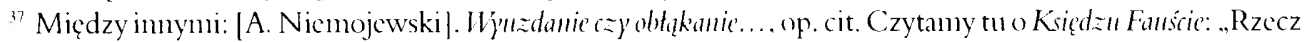
to równic pretensjonalna i bezsensowna, jak skandalicznic niegranuatyczna i niestylistyczna". Podobne zarzuty stawianc są twórczości Nalcpińskicgo.

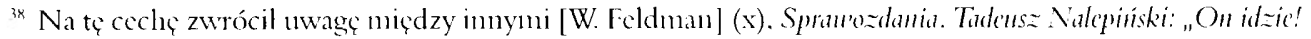
Rzecz o Królu-Duchu Rosji”. ..Krytyka“ 1907 z. 7-8. Czytamy tu:. SSpecjaliści będą mówili o zuawstwic - krytyk literacki hold tylko oddać musi glębokicj intuicyjności i darowi charakteryzacji.jaka siç przcbija z unnóstwa portretów literackich”. Foldman przyznaje, że można mu zarzucić ,jednostronność, naginającą życic i autorów do zasady a priori postawionej (...). Nic roszcząc sobic kompetencji do znawstwa literatury rosyjskicj. w szkicu powyższyn widziny jednak luki zbyt poważnc. braki twórców zbyt wybitnych. aby oswobodzić się od wrażenia zbytnicj tendencyjności. Ostatecznie - kiedyż metafizyka liczyla siç zanadto z cmpiryzmem?”. 
brzmienie słów swego mistrza. „Przedziwne, gorączkowe wizje” ${ }^{39}$ zbliżają nie tylko Chrzest i Nietotẹ, Księdza Fansta i Księcia nieuolnego. Wdzierają się one do szkiców o Micińskim. Mówienie, że jest on tym, „któremu sądzono czytać z ksiąg tajemnych, że jest jak człowiek z dna studni spozierający na świat”, gdy wierzy, i ,jako nadczłowiek, «budowniczy nadgwiezdnych miast”", gdy wątpi ${ }^{+1 \prime}$, nie wskazıje na postawę recenzenta, ale raczej eseisty, zajętego internalizacją omawianych utworów. Sam Nalepiński zresztą pisze o swoim szkicu dotyczącym Walki o Chrjstusa: nie jest to recenzja z przeczytanej ksiązki, lecz raczej wstęp do niej, rzut oka na metodę i .pewne wniosk" "+1. Pisząc o Nietocie, wplata jej opis do toku wlasnych rozważań. Utożsamia się z odnalezionymi w niej sensami, wartościami, odnalezionymi przez siebie jej czytelnikia.

Jak postrzegal swą rolę jako krytyka? Wskazać rzecz, na której można się spotkać z autorem jak na moście - tak określa swoje zadanie, pisząc o Walce o Chry'stusa. Nie clice pośredniczyć, tłumaczyć dzieła na inny język, język krytyki. Chce doprowadzić do możliwie bezpośredniego kontaktu jego autora z czytelnikiem. Dlatego punktem wyjścia jest dla niego w r a ż n i e, i mp resja wyniesiona z kontaktu z utworem. Zamiast objaśniać dzicło - pisze o nim z punktu widzenia czytelnika, subiektywnego, ale i zwróconego ku wspólnocie czytelników myślących i czujących podobnie. W jednym z artykułów czytamy:

Przeczuwam, że w szalonych otchłaniach, jakie rozwarł Miciński w Bazylissie Teofanı, kazdy z czytelników ujrzy inne odbicie swego lucyferyzmu. (...) Dlatego wolno każdemu wizucać swój kamień w przepaść zaiste bezdenną ${ }^{+2}$.

Nietotę zaś odbiera jako dzicło poety, którego wyobraźnia „działa na czytelnika jak haszysz":

Nikt mię nic przekona, że czytając Nietotę, tu przy swym biurku w Paryżu, nie jestem Aryamanem, wspinającym się na urwiska zamku Zulimy. (...) Chcialbym dopomóc uważnemu jej czytehnikowi w przedostawaniu się realnym poprzez mistyczne puszcze - zawsze z całą świadomością ostatecznego celı, który nas wiąze z autorem: Prawdy ${ }^{+3}$.

Nalepiński stawia czytelnikowi - a więc i sobie - wymagania:

Całą mocą wlasnej poezji i wiary uderzmy o kraty, odgradzające nas od poetyckiej wizji, i jeśli ma ona być na wspaniałym rydwanie, spłoszmy konie, zdruzgocmy rydwan, zajrzyjmy poezji w zywą twarz. Potrzeba jak zawsze — odwa-

\footnotetext{
34 S. Pazurkicwicz, op. cit.

+41 T. Nalcpiński. Tadeusza Micinskiego „Bazylissa Teofamm”, op. cit.

+. List do redaktora warszawskicgo z 1910 r. [w:] Listy literatów i uczonych polskich, głównic z XIX wicku, BN III 2674

t2 T. Nalcpinski. O Micinskim. "Tygodnik Ilustrowany” 1969 mr 18, s. 357.

t3 Idem. Tadeusza Micinskiego "Nictota" (Priba wyktadu), op. cit.
} 
gi. Odwaga tutaj, znaczy to: praca myśli, przeżywanie wspólne z poetą, czyli zdobywanie twórcze jego wirchów ${ }^{4+}$.

Styl Nietoty zaś, pozornic tak zawikłany i przepaścisty,

...wyda się bitym gościńcem dla wspaniałego rydwanu, ale tylko wtedy, gdy powolni jego sugesti i magicznej, postanowimy przedzierać się przez metafizyczne paszcze skarłowacialych, a niegdyś olbrzymich lepidodendronów z tym uczuciem ukochania tła - Tatr, ludzi - Turowczyków...

Dlaczego warto poddać się tej sugestii magiczıcj?

Magia Micińskiego to owo organiczne myślenie mickiewiczowskie, dziś może tylko w Polsce możliwe: odkrywanie prawdy jednocześnie myślą i c z ucie $m$, r ozu me m i se r ce $m$ - mistyka instynktów i przeczuć. Na innym miejscu godziloby siç udowodnić, że wszystkie prawdziwie wieszcze utwory pisarzy polskich poczęte zostały w stanie jakiegoś nadprzyrodzonego oglądania rzeczy samych w sobie; że wykonanic ich literackie jest tylko procesem sciosywania i obnażania pewnej mistycznej, objawieniem wskazanej treści; że na skutek tego w Polsce niemożliwym jest stworzenie formalnic doskonalego arcydzieła, ponieważ mina nieokiełznanego, buntowniczego uczucia rozsadza potęga tęsknoty najtęższe murowania intelektu, niby filigranowe koronki wieżyczek, inaczej mówiąc - wszelką formę.

Prawdziwe arcydzieło nie jest skończone, doskonałe formalnie. A więc poszukiwanie „piątej Ewangelii” nie jest szukaniem konkretnego, doskonałego wyrazu w jednym dziele jest „sciosywaniem” tekstów - jej fragmentów, przedzieraniem się przez rozsadzone emocja formy. Przeżywaniem wspólnie z poetą i wyczuciem jego wizji, zawierzeniem jego sugestii, dotyczącej ,jakicjś innej pozarealnej i niesprawdzalnej prawdy".

Prawdę tę wyrażają dość często spiętrzenia symboli, co w ocenie Jana Lorentowicza powoduje, że strofy Chrztu przypominają

...runy, których ksztalty spalone zostały w ogniu duszy. Suną mgły pięknych obrazów, kłębią się olbrzymie metafory „wieszczenia”, niby u Pytii ustawionej na trójnogu nad pieczarą ${ }^{+5}$.

Wśród symboli takich są, jak u Micińskiego, Tatry — „serce granitowe” ojczyzny; są symbole romantycznego mesjanizmu i mitologii greckiej, tworzące wieloznaczne kombinacje, wedlug zasady, że

...im głębszym, samoistniejszym staje się życie, tym ciemniejszymi i trudniej dostępnymi stają się symbole, gdyż tym bardziej nieprzewidzianymi i niezwy-

"Idem, Tadeusza Micinskicgu „Nictotu”, ..Literatura i Sztuka”, op. cit.

${ }^{15}$ J. Lorentowicz, op. cit. "Literatura i Sztuka” 1911 nr 11. 
kłymi stają się widzenia, napotykane przez poetę na samotnych, przez nikogo nieuczęszczanych drogach, drogach jego własnej duszy ${ }^{\text {th }}$.

Lorentowicz określa Chrzest, w którym Nalepiński — jak sam stwierdza we wstępie do swego utworu - zamknąl „cale swoje Ja”, jako ,jeden z etapów jego poetyckiej wędrówki do źródeł duszy narodowej" ${ }^{+7}$. Nalepiński chce dotrzeć do istoty ducha Polaków choćby poprzez zniszczenie iluzji o nich, ukazanie ich najglębszych kompleksów. Właśnie to sięganie glębin duszy narodowej Miciński cenil u Nalepińskiego, rozpoczynając szkic o jego książce On idzie! slowami:

W Polsce dzisiejszej nie wolno glęboko zaglądać i wpatrywać się w tajnie duszy. Biedni my! (...) Inaczej kochal Rosję Dostojewski —

którego Nalepiński uczynil jednym z głównych bohaterów swej pracy.

Jako zapowiedź kolejnego etapu twórczości Lorentowicz traktuje cytat z artykulu Nalepińskiego w "Tygodniku Ilustrowanym" ${ }^{\text {t\$: }}$

W echach groźnego dnia wczorajszego słyszymy i żal, i gorycz, i skargę, ale zamilkły juź śpiewy Tyrteuszowe... Potrze ba nam budowniczych więc sięgnijcie do rumowisk polskiego ducha, odrzućcie gruzy i próchno, a znajdziecie jeszcze dość kamienia i metalu na sypanie podwalin dla obronnego zamku (...) potrzebua tu pełna nadziei pieśń Legionów, z ukochania, karności i zapału poczęta, potrzebny śpiew Zygfryda, radośnie skuwającego szczątki miccza.

Jak wiele tu Micińskiego, ale i innych „budzicieli narodu”: Słowackiego, Wyspiańskiego, Żeromskiego, Struga. Nalepiński przeżywa ich wizje, buduje z nich swoją twórczość. Wiele fragmentów Chrztu zbudowanych jest z parafraz wersów Żeromskiego, Wyspiańskiego, Słowackiego, Mickiewicza. Jest to jednak zamierzone. Poeta wrosly w tradycję czerpie z niej, by rozwinąć swą myśl.

Tę zależność od twórczości i poglądów innych twórców zauważyl już w pracy o KróIn-Duclu Rosji Adam Grzymała-Siedlecki ${ }^{+4}$. Nazywa ja łatwowiernością, niewolniczym zamiłowaniem do bogatego i pięknego piśmiennictwa. W jego ocenie postawa Nalepińskiego jest krokiem wstecz. Jednak tak nie jest: szkice Nalepińskiego nie są bowiem krytyką literacką mającą za zadanie recenzować czy opisywać. To raczej rodzaj dokumentu osobistego, utrwalającego ksztaltowanie się myśli, poszukiwanie potwierdzenia dla wlasnych przekonań w dziełach innych twórców. Taka postawa nie była jego ulomnością: był przecież w stanie pi-

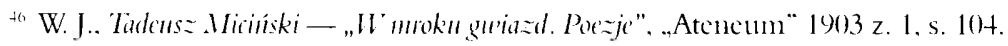

47 ..Litcratura i Sztuka” 191111111.

to T. Nalepiński. Apostolituo smutku, .. Tygodnik llustrowany" 1911 ur 3. s. 44.

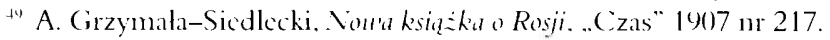


Sać inaczej, trzeźwo, a nawet dowcipnie oceniając zjawiska kultury. Świadczą o tym chociażby jego szkice teatralne ${ }^{51 !}$.

Czy, komponując swą twórczość z poglosów twórczości innych, był bardziej myślicielem czy poetą? Zdania były podzielone już za jego życia. Wedłıg Jana Lorentowicza był raczej myślicielem ${ }^{51}$. Wedlug Wilhelma Feldmana - poeta ${ }^{52}$.

Ezoteryzm Nalepińskiego operuje chętniej pozytywnymi metodami poznania niż „ekstazą" - pisze Lorentowicz — i stąd w nim dotychczasowa przewaga wytężonej, gómej, namiętnej ideologii nad bezpośrednią twórczością poetycką.

Ideologia ta, wyrażająca się w nieustannym roztrząsaniu faktów zbiorowego życia, odwoływala się do mesjanizmu ${ }^{53}$ - ale nie jako skladania z Polski ofiary chrystusowej za grzechy świata. Odnosi się do mesjanizmu „niewyrzekającego się ani jednego sposobu walki o wolność bezwzględną, zdobywczego, świadomego odrębności duchowej Polski”. W myśl tej ideologii Nalepiński ocenia Ozimine Wactawa Berenta ${ }^{5+}$ jako

...pstrą mozaikę myśli, szlifowanych przez pierwszorzędnego artystę-cyzelatora, kombinowanych przez gorszego znacznie ideologa, zdobiących posadzkę niesłychanie słabej, jak na polskiego ducha, świątyni.

W ocenie tej nie zgadza się bowiem na tworzenie gabinetowych powieści, nieprowadzących do rozwiązania problemów „woli czynı, która w Polsce bardziej niż gdzieniegdzie jałowieje" $\overline{\text { s. }}$.

Ta namiętna ideologia to kolejne źródto tak emocjonalnej, zaangażowanej krytyki literackiej. Ona też nadaje ton utworom poetyckim Nalepińskiego. W Chrzcie wyraża się w marzeniı:
Ach, jeśli Polska już ma być Chrystusem - niech na nią spadnie Weroniki chusta (...)
Niech nam nie będzic boska ręka musem,
lecz niech uśniechem oczaruje usta - niech każdy gwóźdź, wdrążony w żywe cialo, na wieki krzyczy: już się dokonało ${ }^{5(! !}$ !

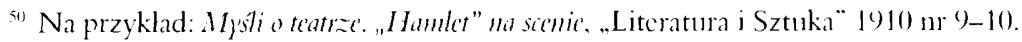

51 .Literatura i Sztuka” 1911 nr 11.

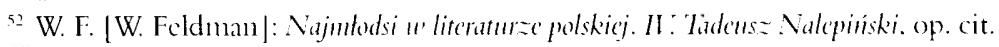

${ }_{53}$ Por. T. Nalepiniski |wstęp do:] Cluzest. Fantazja polska. Kraków 1910.

5 Idem, „Ozimina”. .Litcratura i Sztuka” 1911 11r 5. s. 1-2.

55 Ibidem. Nalepiński-recenzent pisze dalej: „Daremnic szukan w powieści autora Pródma stonecznego węzla... Daremnic? Lecz oto przyponninają mi siç "slowa” Barona (...): - Należy ukochać życie - mówi do szeroko otwartych oczu Niny baron - nad smutek wszystkiego. co jest. lub hyć moze (...). Ach, dlaczegóż to auttor (...) nic rozwinąl przed nami "dramatycznic" tezy barona o losach w Rolsce dziclności czynu?".

sh Idem, Chrzost. Fantazja polska, op. cit., s. 135.
} 
Z kolei Feldman docenia bogactwo widzeń, tempo rytmów Chrztu. Woli czytać tę „jedną z najpoetyczniejszych książek" niż spierać się z jej autorem o słuszność teorii o korzeniach myśli polskiej:

Nie w stronie myślowej istota poezji Pańskiej, lecz w uczuciu. Żyje w Panu ta cicha ekstaza, która poecie świat uświęca, świat przeobraża, świat każe przeżyć w halucynacjach i uniesieniach. Ekstatycznym też styl Pański, halucynacjami widzenia, uświęconym Dobro i Zło, jako jednakowej potęgi dźwignie duszy.

Być może obaj krytycy, zarówno Feldman, jak i Lorentowicz, mieli rację. Przecież to uświęcenie świata w ekstazie, jego przeżycie w uniesieniu nie wyklucza „organicznego myślenia mickiewiczowskiego", odkrywania prawdy myślą i czuciem. Przecież recenzja Ozimi"1'. zanim nazwie utwór „pstrą mozaiką myśli”, rozpoczyna się pełną ekspresji i symboliki narracją o sponiewieranym i ogarniętym niemocą gladiatorze polskim, który nasłuchuje pieśni niosącej slowa otuchy. „Nie mogę nie zacząć tak lirycznie, gdy mam mówić o Oziminie Wacława Berenta", powieści poruszającej, lecz nie przynoszącej nadziei ani mobilizacji do działania - usprawiedliwia się Nalepiński .

Być może Nalepiński był lepszym myślicielem niż poetą. Czasem jakby umyślnie zapomina o tym, że ksztalt utworu musi wyrażać jego zanysl, aby ten byl jasno odczytany ${ }^{57}$. Ta jego niedbałość - to może jednak ostentacyjne wskazanie na brak dostatecznie pojemnej formy?

Szkice literackie Nalepińskiego można uznać za klucz do zrozumienia charakteru jego twórczości. Zaś jego przyjaźnie - w tym nawiązaną później przyjaźń z Andrzejem Strugiem, który zresztą także pozostawał pod urokiem Micińskiego ${ }^{58}$ — wskazówką do uzupełnień jego twórczej autobiografii, w której tak silnie koleje życia splotly się z charakterem i losem utworów.

Myśliciel, który uważal się za poetę. Poeta w tekstach krytycznych. Niedookreślenie jego twórczości, której najbardziej reprezentatywne utwory Lorentowicz określił we wspomnianym artykule jedynie jako etap ${ }^{59}$ - to Nalepiński, jakiego zapamiętano, a potem - zapomniano, zniechęcając się do twórczego niezdecydowania.

57 Zarzut ten postawil mu jan Lorentowicz we wspomnianym artykule.

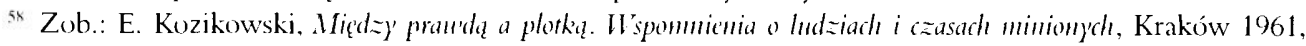
s. 97-98 (rozdz. Andrzcj Stmg); hasło Anny Micińskicj, op. cit.: K. Kolińska: List)' do niekechany'ch, op. cit. , Tadzia opętala kolejna fascynacja - nie wypierająca Micińskiego, ale równolegla: Andrzcjem Strugiem .." (H. Nalepińska-Pieczarkowska. Tadensz Nulepinski na tle rodziny, op. cit., s. 83). Zob. też: T. Nalepiński, O. Audrzeju Strugu, ..Literatura i Sztuka” 1911 ur 17.

¡s "Nalepiński jest w epoce mozolnego tworzenia samego sicbic. Okres to jeszcze mglawicowy. W poecie toczy siç dzisiaj wciąż plomicnna walka pomięc dzy jego uczuciem, żądnym rozlewności lirycznej, a jego niespokejną myśla. poszukiując gorączkowo Idcalü." (J. Lorcntowicz. Tadcusz Nalcpiniski. op. cit.). 
"Za trudna” twórczość Micińskiego ${ }^{(0)}$, jego zbyt hermetyczne dla szerokicj publiczności rozumienie „duszy polskiej” i „metafizyka, której nadawano obelżywe lub entuzjastyczne określenie" "() , rzucają pewne oświctlenie na problem nieobecności Nalepińskiégo w świadomości literackiej pokoleń. Propagując twórczość swego mistrza, otrzymal etykictkę epigona, naśladującego w dodatku niezrozumiałego artystę.

Do ukonstytuowania tej opinii przyczyniło się wicle faktów: przedwczesma śmierć twórcy, wydanie tylko jednego, wczesnego tomu poezji i rozproszenie późniejszych utworów poetyckich po licznych czasopismach, niemożność przedstawienia publiczności - zarówno w formie książki, jak i inscenizacji — dramatu, który uważał za dzicło swego życia: Ksiaźe nie-

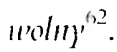

Owszem, można określić charakter jego twórczości zależnościami od mistrzów, zwhaszcza od Micińskiego. Po bliższym poznaniu apologia Micińskiego okazuje się jednak „apologią tezy o potrzebie religii dla duszy polskiej współczesnej" ".3. Może zatem warto rozpoznać indywidualny charakter tego prawie nicznanego poety, podróżnika, reportażysty (Pazurkiewicz uważa, że reportaże z podróży na Islandię zasługują na oddzielne opublikowanie), wedhug niektórych megalomana i narcyza, wedlıg przyjaciól - czlowieka obdarzonego blyskotliwą inteligencją i poczuciem humoru.

Ile w nim bylo z apologety, a ile z oryginalnego twórcy? Pytanie takie, postawione w stosunku do twórców dzisiejszych, którzy oficjalnie tworzą swe światy z form już istniejących, wydawałoby się naiwne. Nadużyciem byloby przekreślić tradycję i kategorie, według których dawniej postrzegano dzieła, ale może potrzebna jest nowa perspektywa, która pozwoli odkryć dla literatury Tadeusza Nalepińskiego. Pozwoli ukazać jego drogę poszukiwań wspólnoty z czytehnikiem, jego intuicje, impresje oraz zaproponowane przez niego nowe rozumienie mesjanizmu, mistycyzmu, metafizyki - pojęć związanych z zakorzenioną w romantyzmie poezją, która ma zmienić kraj

(fil Edward Kozikowski (op. cit.) wsponina, że picruszy tom pism Micińskiego wydany w 1931 roku rozszedl siç w znikonnej lic zbie egzemplarzy i nie pokrył nawet dziesiątej części wylożonych na druk finduszy. Na dalsze tomy nie można było znalcźć wydawcy.

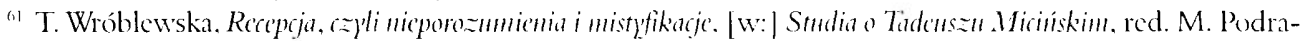
za-Kwiatkowska, Kraków 1979.

${ }^{62}$ Dramat ten, wyznaczający rỵtm przenian twórczości Nalepińskiego. zasługuje na osobne onówienic. W liście do Willhehna Feldnana. pisanym z Paryża 13 czerwca 1914. Nalepiński odpowiada na prośbę o podsumowanic dziesiçciu lat swojcj pracy: „uważalbym za nickompletne ledwie sprawozdanic. dopóki dramat mój

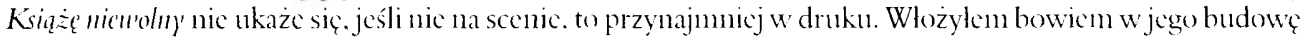
całą wlasną idcologiç teatru dwoistego. (...) Zly los ściga ten mój utwór — parç razy już mial być grany. Alc nagle siç dyrcktorowic rozmyślali. Az wreszcic, gdy go usprzedalem” we Lwowic na jesicni r|oku| z|cszlego] spółce (...) ze "Sceny i Ekrann". pismo nic tylko zrobiło klapç. ale nawet wygrawszy proces o odszkodowanic (...) w żaden sposób nic mogę tej stmny wydobyć. A to bylaby jedyna droga materialna do wydania rzeczy whasnym nakladem".

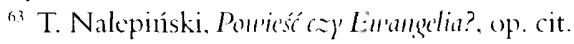


...szumnnych słów i uroczystych mów, gdzie święcimy umarłych, a gubimy żywych, gdzie prawda jest warcholstwem, a nogi służą nie do stąpania na szczeble postępu, a do podstawiania bliźnimºt.

at Z listu T. Nalcpińskicgo do W. Feldmana z Ameryki, b. d. 